\title{
Prospective genetic profiling of squamous cell lung cancer and adenosquamous carcinoma in Japanese patients by multitarget assays
}

Hirotsugu Kenmotsu ${ }^{1,2^{*}}$, Masakuni Serizawa ${ }^{2}$, Yasuhiro Koh ${ }^{2}$, Mitsuhiro Isaka ${ }^{3}$, Toshiaki Takahashi ${ }^{1}$, Tetsuhiko Taira ${ }^{1}$, Akira Ono ${ }^{1}$, Tomohiro Maniwa ${ }^{3}$, Shoji Takahashi ${ }^{3}$, Keita Mori ${ }^{4}$, Masahiro Endo ${ }^{5}$, Masato Abe ${ }^{6}$, Isamu Hayashi ${ }^{6}$, Takashi Nakajima6, Yasuhisa Ohde ${ }^{3}$ and Nobuyuki Yamamoto ${ }^{1,7}$

\begin{abstract}
Background: Despite considerable recent progress in the treatment of lung adenocarcinoma, there has been little progress in the development of efficacious molecular targeted therapies for squamous cell lung cancer. In addition to the recent comprehensive genome-wide characterization of squamous cell lung cancer, it is also important to genotype this form of cancer. We therefore conducted the Shizuoka Lung Cancer Mutation Study to analyze driver mutations in patients with thoracic malignancies. Here we report the results of genotyping in patients with squamous cell lung cancer.
\end{abstract}

Methods: Based on the biobanking system, in conjunction with the clinic and pathology lab, we developed a genotyping panel designed to assess 24 mutations in 10 genes (EGFR, KRAS, BRAF, PIK3CA, NRAS, MEK1, AKT1, PTEN, HER2 and DDR2), EGFR, MET, PIK3CA, FGFR1 and FGFR2 copy numbers, and EML4-ALK and ROS1 translocations, using pyrosequencing plus capillary electrophoresis, quantitative polymerase chain reaction (PCR) and reverse-transcription $P C R$, respectively.

Results: A total of 129 patients with squamous cell lung cancer and adenosquamous carcinoma were enrolled in this study between July 2011 and November 2012. We detected genetic alterations in 40\% of all cases. Gene alterations included: EGFR mutations, 6\%; KRAS mutations, 4\%; PIK3CA mutations, 13\%; NRAS mutations, 1\%; KIF5b-RET fusion gene, 1\%; EGFR copy number gain, 5\%; PIK3CA copy number gain, 15\%; and FGFR1 copy number gain, 5\%. Twelve patients (9\%) harbored simultaneous genetic alterations. Genetic alterations were detected more frequently in surgically-resected, snap-frozen samples than in formalin-fixed, paraffin-embedded samples (50\% vs. 29\%). In addition, patients aged $\leq 70$ years old and never-smokers showed high frequencies of genetic alterations.

Conclusions: This study represents one of the largest prospective tumor-genotyping studies to be performed in Asian patients with squamous cell lung cancer. These results suggest that incorporation of genetic profiling into lung cancer clinical practice may facilitate the administration of personalized cancer treatments in patients with squamous cell lung cancer.

Keywords: Lung cancer, Squamous cell carcinoma, Adenosquamos carcinoma, Genetic profiling, Driver mutation, PIK3CA mutation, FGFR1 copy number gain

\footnotetext{
* Correspondence: h.kenmotsu@scchr.jp

'Division of Thoracic Oncology, Shizuoka Cancer Center, 1007

Shimonagakubo, Nagaizumi-cho, Sunto-gun, Shizuoka 411-8777, Japan

${ }^{2}$ Division of Drug Discovery and Development, Shizuoka Cancer Center

Research Institute, Nagaizumi-cho, Sunto-gun, Japan

Full list of author information is available at the end of the article
} 


\section{Background}

Non-small-cell lung cancer (NSCLC) has recently been divided into nonsquamous cell carcinoma and squamous cell carcinoma. Pemetrexed and bevacizumab have been approved for the treatment of nonsquamous cell lung cancer $[1,2]$. In addition, epidermal growth factor receptor $(E G F R)$ mutations and anaplastic lymphoma kinase $(A L K)$ fusion genes have been identified in lung adenocarcinoma, and are considered as biomarkers for EGFR and ALK inhibitors [3-7]. Treatment for nonsquamous cell lung cancer has therefore advanced, including options for personalized therapy.

Squamous cell lung cancer is a major histological subtype of NSCLC, accounting for 30\% of NSCLC. However, in contrast to adenocarcinomas, little progress has been achieved in the development of efficacious molecular

Table 1 Multiple tumor genotyping panel

\begin{tabular}{|c|c|c|c|}
\hline Gene & Position & AA mutant & Nucleotide mutant \\
\hline \multirow[t]{7}{*}{$\overline{E G F R}$} & G719 & G719C/S & $2155 G>T / A$ \\
\hline & & G719A & $2156 G>C$ \\
\hline & exon 19 & deletion & \\
\hline & T790 & T790M & $2369 C>T$ \\
\hline & exon 20 & insertion & \\
\hline & L858 & L858R & $2573 \mathrm{~T}>\mathrm{G}$ \\
\hline & L861 & L861Q & $2582 \mathrm{~T}>\mathrm{A}$ \\
\hline \multirow[t]{7}{*}{ KRAS } & G12 & $\mathrm{G} 12 \mathrm{C} / \mathrm{S} / \mathrm{R}$ & $34 G>T / A / C$ \\
\hline & & G12V/A/D & $35 G>T / C / A$ \\
\hline & G13 & G13C/S/R & $37 G>T / A / C$ \\
\hline & & G13D/A & $38 G>A / C$ \\
\hline & Q61 & Q61K & $181 C>A$ \\
\hline & & Q61R/L & $182 \mathrm{~A}>\mathrm{G} / \mathrm{T}$ \\
\hline & & Q61H & $183 \mathrm{~A}>\mathrm{T} / \mathrm{C}$ \\
\hline \multirow[t]{4}{*}{$B R A F$} & G466 & G466V & $1397 G>T$ \\
\hline & G469 & G469A & $1406 G>C$ \\
\hline & Ł597 & L597V & $1789 C>G$ \\
\hline & V600 & V600E & $1799 \mathrm{~T}>\mathrm{A}$ \\
\hline \multirow[t]{3}{*}{ PIK3CA } & E542 & E542K & $1624 G>A$ \\
\hline & E545 & E545K/Q & $1633 G>A / C$ \\
\hline & H1047 & H1047R & $3140 A>G$ \\
\hline \multirow[t]{2}{*}{ NRAS } & Q61 & Q61K & $181 C>A$ \\
\hline & & Q61L/R & $182 \mathrm{~A}>\mathrm{T} / \mathrm{G}$ \\
\hline \multirow[t]{3}{*}{ MEK1 (MAP2K1) } & Q56 & Q56P & $167 A>C$ \\
\hline & K57 & K57N & $171 \mathrm{G}>\mathrm{T}$ \\
\hline & D67 & D67N & $199 G>A$ \\
\hline AKT1 & E17 & E17K & $49 G>A$ \\
\hline PTEN & $R 233$ & $\mathrm{R} 233^{*}$ & $697 \mathrm{C}>\mathrm{T}$ \\
\hline HER2 & exon 20 & insertion & \\
\hline DDR2 & S768 & S768R & $2304 \mathrm{~T}>\mathrm{A}$ \\
\hline
\end{tabular}

targeted therapies for squamous cell lung cancer. Comprehensive genome-wide characterization of squamous cell lung cancer has recently revealed some potential drug targets [8-10]. However, differences in frequencies of some genetic alterations, including EGFR and KRAS mutations, have been identified between Asian and Western patients [11], and it is therefore important to assess the frequencies of genetic alterations in squamous cell lung cancer in different ethnic groups, including in Asian patients.

We developed a tumor-genotyping panel to screen lung cancer patients for genetic alterations relevant to novel molecular-targeted therapeutics in ongoing clinical trials [12-15] (Additional file 1: Table S1). Genotyping analysis was implemented in the Shizuoka Lung Cancer Mutation Study, which is a prospective tumor-genotyping study conducted in patients admitted to Shizuoka Cancer Center with thoracic malignancies. This paper reports the results of this study in relation to genetic alterations in squamous cell lung cancer and adenosquamous carcinoma.

\section{Methods}

\section{Patients and samples}

The Shizuoka Lung Cancer Mutation Study was initiated in July 2011 to analyze driver mutations in patients with thoracic malignancies. The study subjects were patients

Table 2 Patient characteristics (overall, $\mathbf{n}=129$ )

\begin{tabular}{|c|c|c|}
\hline & $N=129$ & (\%) \\
\hline Median age (years) & 70 & \\
\hline (range) & $(38-92)$ & \\
\hline \multicolumn{3}{|l|}{ Gender } \\
\hline Male & 111 & 86 \\
\hline Female & 18 & 14 \\
\hline \multicolumn{3}{|l|}{ Smoker } \\
\hline Never & 3 & 2 \\
\hline Light (pack-year <30) & 12 & 9 \\
\hline Heavy (pack-year $\geq 30$ ) & 114 & 89 \\
\hline \multicolumn{3}{|l|}{ Histology } \\
\hline Squamous & 123 & 95 \\
\hline Adenosquamous & 6 & 5 \\
\hline \multicolumn{3}{|l|}{ Differentiation } \\
\hline Well & 13 & 10 \\
\hline Moderately & 69 & 53 \\
\hline Poorly & 35 & 27 \\
\hline Unknown & 6 & 5 \\
\hline \multicolumn{3}{|l|}{ Stage } \\
\hline I & 33 & 26 \\
\hline$\|$ & 38 & 29 \\
\hline III & 34 & 26 \\
\hline IV & 24 & 19 \\
\hline
\end{tabular}


with pathologically-diagnosed thoracic malignancies, who had provided written informed consent. The diagnosis and differentiation of squamous cell carcinoma and adenosquamous carcinoma were confirmed by institutional pathologists, in accordance with the 2004 World Health Organization classification. When samples were difficult to diagnose as squamous cell carcinoma, immunohistochemical analyses were performed (i.e., thyroid transcription factor 1, p63 staining). Surgically-resected tissue specimens were macrodissected by the same pathologists to enrich the tumor content. Tumor biopsy specimens containing $\geq 10 \%$ tumor content, as evaluated by hematoxylineosin staining, were used for this study. All specimens from 129 patients with squamous cell lung cancer were thus considered adequate for genotyping. Surgically-resected tissues were snap-frozen on dry ice immediately after resection and stored at $-80^{\circ} \mathrm{C}$ until use. Formalin-fixed, paraffin-embedded (FFPE) specimens, mainly including biopsy samples, were sectioned at a thickness of $10 \mu \mathrm{m}$. All the relevant clinicopathological information, including smoking history, was retrieved from the patients' medical records. We defined "light smokers" as those who smoked $<30$ packs per year, and "heavy smokers" as those who smoked $\geq 30$ packs per year.

\section{Genetic profiling}

We developed a tumor genotyping panel (Table 1) to assess 24 hot-spot sites of genetic alterations in 10 genes (EGFR, KRAS, BRAF, PIK3CA, NRAS, MEK1, AKT1, PTEN, HER2 and DDR2), EGFR, MET, PIK3CA, FGFR1 and FGFR2 copy number gains, and EML4-ALK, KIF5B-RET, CCDC6RET, CD74-ROS1 and SLC34A2-ROS1 fusion genes using

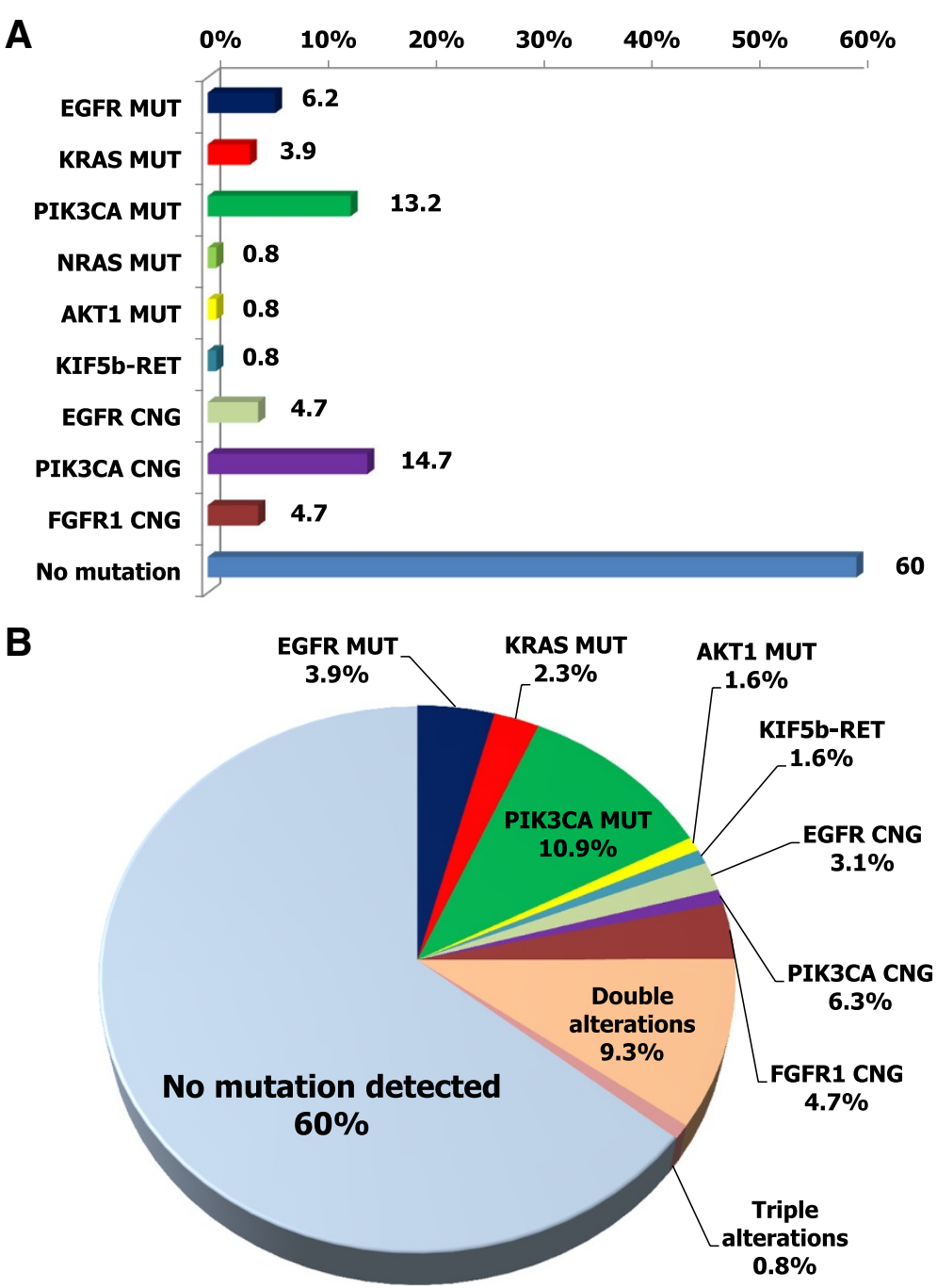

Figure 1 Relative proportions of genetic alterations in squamous cell lung cancer and adenosquamous carcinoma (overall, $\mathrm{n}=129$ ). A: Pie chart shows relative proportions of genetic alterations. B: Bar chart shows relative proportions of genetic alterations. MUT: mutant, CNG: copy number gain. 
pyrosequencing plus capillary electrophoresis, quantitative polymerase chain reaction (PCR), and reversetranscription PCR, respectively. These genetic alterations were selected based on the articles listed in Additional file 1: Table S1. Detailed methods are described in Additional file 2 [16]. Fusion genes were accessed only with fresh-frozen tissues.

\section{Statistical analysis}

All categorical variables were analyzed by $\chi^{2}$ or Fisher's exact tests, as appropriate. All p values were reported as twosided, and values $<0.05$ were considered statistically significant. This study was approved by the Institutional Review Board of the Shizuoka Cancer Center (22-34-22-1-7).

\section{Results}

Patient characteristics

A total of 129 patients were diagnosed with squamous cell lung cancer or adenosquamous carcinoma and were included in this study from July 2011 to November 2012. The characteristics of the patients are shown in
Table 2. The median age was 70 years (range: 38-92), and most patients were male and smokers. Histologically, adenosquamous carcinoma was observed in six (5\%) of the patients. Well-differentiated, moderately-differentiated and poorly-differentiated squamous cell carcinomas were present in $10 \%, 53 \%$ and $27 \%$ of the patients, respectively. Stage I, II, III and IV were observed in 26\%, 29\%, 26\% and $19 \%$, respectively. Surgically-resected, snap-frozen samples were obtained from 64 patients (50\%), and FFPE samples from 65 patients $(50 \%)$.

\section{Genetic alteration profiles}

We detected genetic alterations in $40 \%$ of all cases. Figure 1 shows the frequencies of genetic alterations in patients with squamous cell lung cancer. The genetic alterations included: EGFR mutation in eight (6\%); KRAS mutation in five (4\%); PIK3CA mutation in 17 (13\%); NRAS mutation in one (1\%); KIF5b-RET fusion in one (1\%); EGFR copy number gain in six (5\%); PIK3CA copy number gain in 19 (15\%); and FGFR1 copy number gain in six (5\%) (Additional file 3: Table S2 and Additional file 4: Table

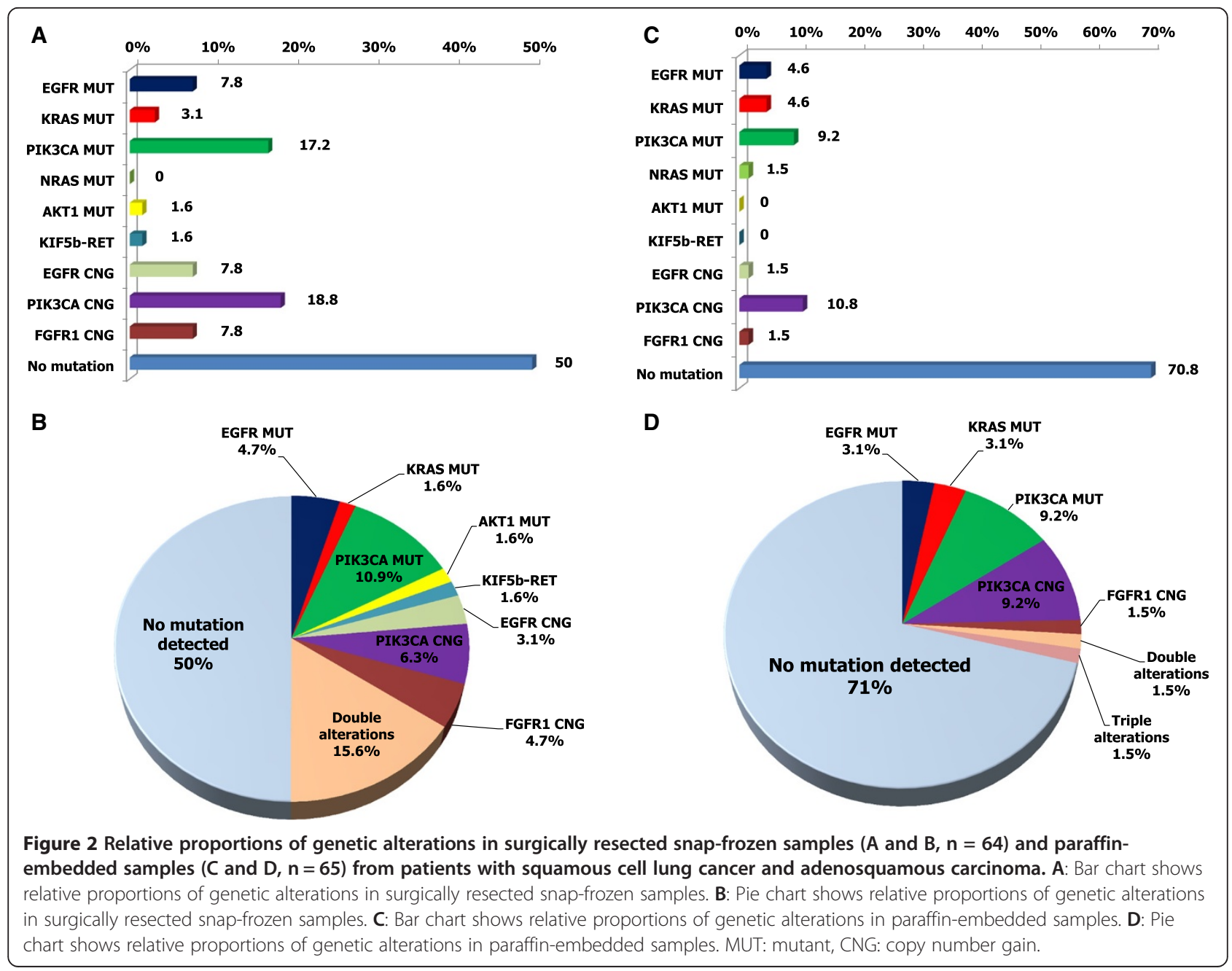


S3). Of eight patients with EGFR mutation, four had the L858R point mutation in exon 21, and three had deletions in exon 19. In addition, the frequencies of genetic alterations in surgically-resected, snap-frozen samples and FFPE samples from patients with squamous cell lung cancer were analyzed (Figure 2), and the following alterations were detected: EGFR mutation in $8 \%$ and $5 \%, K R A S$ mutation in $3 \%$ and $5 \%$, PIK3CA mutation in $17 \%$ and $9 \%$, EGFR copy number gain in $8 \%$ and $2 \%, P I K 3 C A$ copy number gain in $19 \%$ and $11 \%$, and FGFR 1 copy number gain in $8 \%$ and $2 \%$, respectively.

\section{Clinicopathological factors related to genetic alterations}

The results of univariate analysis of clinicopathological factors for genetic alterations are shown in Table 3. Genetic alterations were significantly more frequent in surgically-

Table 3 Frequency of genomic alterations in clinicopathological factors (overall, $n=129$ )

\begin{tabular}{|c|c|c|c|c|}
\hline & \multicolumn{2}{|c|}{ Genomic alterations } & \multirow{2}{*}{$\underset{\text { value }}{p}$} \\
\hline & & $(+)$ & $(-)$ & \\
\hline \multirow[t]{3}{*}{ Age } & & & & 0.027 \\
\hline & $\leq 70$ years & 33 & 35 & \\
\hline & $>70$ years & 18 & 48 & \\
\hline \multirow[t]{3}{*}{ Gender } & & & & N.S. \\
\hline & Male & 44 & 67 & \\
\hline & Female & 7 & 11 & \\
\hline \multirow[t]{4}{*}{ Smoker } & & & & 0.035 \\
\hline & Never & 3 & 10 & \\
\hline & Light (pack-year <30) & 3 & 9 & \\
\hline & Heavy (pack-year $\geq 30$ ) & 45 & 69 & \\
\hline \multicolumn{2}{|l|}{ Histology } & & & N.S. \\
\hline & Squamous & 49 & 74 & \\
\hline & Adenosquamous & 2 & 4 & \\
\hline \multicolumn{2}{|c|}{ Differentiation } & & & N.S. \\
\hline & Well & 5 & 8 & \\
\hline & Moderately & 27 & 42 & \\
\hline & Poorly & 15 & 20 & \\
\hline & Unknown & 2 & 4 & \\
\hline \multirow[t]{5}{*}{ Stage } & & & & N.S. \\
\hline & । & 13 & 20 & \\
\hline & $\|$ & 12 & 26 & \\
\hline & $\|$ & 16 & 18 & \\
\hline & IV & 10 & 14 & \\
\hline \multirow[t]{3}{*}{ Samples } & & & & 0.015 \\
\hline & Snap-frozen & 32 & 32 & \\
\hline & FFPE & 19 & 46 & \\
\hline
\end{tabular}

FFPE formalin-fixed paraffin-embedded. resected, snap-frozen samples than in FFPE samples $(50 \%$ vs. $29 \%, p=0.015$ ). In addition, patients $\leq 70$ years old and "never-smokers" showed higher frequencies of genetic alterations. Also, $75 \%$ of patients $\leq 60$ years old $(n=12)$ had genetic alterations including EGFR mutation in 2, KRAS mutation in 2, PIK3CA mutation in 2, KIF5b-RET fusion in 1, EGFR copy number gain in 2, and PIK3CA copy number gain in 2 .

\section{Discussion}

This study represents one of the largest, prospective, tumor-genotyping studies carried out in Asian patients with squamous cell carcinoma of the lung. Genetic alterations were detected in $40 \%$ of patients in this study. There have been few reports on the gene alterations associated with squamous cell lung cancer. However, the Cancer Genome Atlas Research Network performed a comprehensive genomic analysis of 178 squamous cell lung cancers and reported the following genetic alterations: PIK3CA mutations in 16\%, PTEN mutation/deletion in $15 \%$, FGFR1 amplification in 15\%, EGFR amplification in 9\%, PDGFRA amplification in 9\%, DDR2 mutation in $4 \%$, and unknown genetic alterations in $21 \%$ [8]. In addition, multiplex testing for driver mutations in 72 squamous cell carcinomas of the lung detected: PIK3CA mutations in $8 \%$, PTEN mutation/deletion in 28\%, FGFR1 amplification in $26 \%$, and unknown genetic alterations in $39 \%$ [9]. Korean study showed a similar spectrum of gene alterations between East Asian and North American [10]. Genetic alterations in patients enrolled in the current prospective study may reflect the frequencies of genetic alterations in the clinical setting, and suggest that genetic profiling in Japanese patients may be similar to that in North American.

Genetic alterations were seen more frequently in surgically-resected, snap-frozen samples, in patients $\leq 70$ years old, and in "never-smokers". FFPE specimens are subject to increasing DNA degradation as they get older [17], which may account for the difference in frequencies of genetic alterations between snap-frozen and FFPE samples. Squamous cell lung cancer is strongly associated with cigarette smoking [18] and 98\% of patients with squamous cell carcinoma in this study were light or heavy smokers. Although all three "never-smokers" showed genetic alterations (EGFR mutation, EGFR or PIK3CA copy number gain), the sample size was too small to evaluate these results. The association between age and genetic alterations is unclear. Multiple genetic alterations were reported to be more common in younger patients with papillary thyroid cancer [19], while younger patients with colorectal cancer showed a high frequency of KRAS mutations [20]. In contrast however, a positive association between EGFR mutation and age was reported among never-smoker lung cancer patients [21]. 
In this study, PIK3CA mutation was relatively frequent in squamous cell lung cancer, as reported in other studies, while FGFR1 copy number gain seemed less frequent $[8,9]$. The phosphoinositide 3-kinase (PI3K) pathway is a key oncogenic signaling pathway that functions in cell survival and proliferation [22]. The PIK3CA gene encodes the PI3K catalytic subunit $\alpha$-isoform and is frequently mutated in some of the most common human tumors. Our earlier study, as well as other studies, found that PIK3CA mutations were more common in squamous cell lung cancer than in lung adenocarcinoma [23-25]. The fibroblast growth factor receptor (FGFR) is a transmembrane receptor tyrosine kinase that participates in the regulation of embryonal development, cell proliferation, differentiation, and angiogenesis [26,27]. The frequency of FGFR1 amplification in surgical specimens has been reported to be $13-41 \%$, and does not seem to differ according to ethnicity [28-30]. However, the frequency of FGFR1 copy number gain in this study was only $4 \%$ of all samples and $8 \%$ of freshfrozen samples. This apparent discrepancy in the frequencies of FGFR1 copy number gain may be a result of the different methodologies used in the studies, and/or the influence of biopsy samples from patients with metastatic squamous cell lung cancer. PIK3CA mutation and FGFR1 amplification both represent potential targets for personalized squamous cell lung cancer therapy, and it may therefore be important to analyze both these gene alterations in clinical practice.

A major limitation of this study was that genetic alterations were analyzed using a genotyping panel, rather than by a comprehensive analysis. However, the objective of this study was not only to assess the frequencies of driver gene mutations, but also to assign patients to appropriate therapies and/or enrollment in clinical trials. Our genotyping panel included most gene mutations that are targeted by new drugs in ongoing clinical trials. This study was also limited by intratumor heterogeneity, which may have resulted in underestimation of tumor genetic alterations [31]. It is difficult to obtain multiple lesions by tumor biopsy in the clinical setting, but we intend to address this challenge in the future to aid further progress in biomarker development.

\section{Conclusion}

Genetic alterations were detected in $40 \%$ of Japanese patients with squamous cell lung cancer. These results suggest that incorporation of genetic profiling into lung cancer clinical practice may facilitate the administration of personalized cancer treatments in patients with squamous cell lung cancer, though further studies are needed to verify these results.

\section{Additional files}

Additional file 1: Table S1. Tumor genotyping panel developed for
this study.
Additional file 2: Supplementary methods.
Additional file 3: Table S2. Distribution of genetic alterations in each
gene.

Additional file 4: Table S3. Distribution of concurrent genetic alterations.

Competing interests

The authors declare that they have no competing interests.

\section{Authors' contributions}

$H K, M S, Y K, T T$, and NY participated in the design of the study and drafted the manuscript. MS, YK, MA, $I \mathrm{H}$, and TN carried out the molecular genetic studies. MI, TT, AO, TM, ST, ME, YO conceived of the study, and participated in its design and coordination and helped to draft the manuscript. KM participated in the design of the study and performed the statistical analysis. All authors read and approved the final manuscript.

\section{Acknowledgments}

We thank all the patients who participated in this study and their families. We also thank Ms. Mie Yamada (Division of Thoracic Oncology, Shizuoka Cancer Center) for data management, Ms. Akane Naruoka and Ms. Junko Suzuki (Division of Drug Discovery and Development, Shizuoka Cancer Center Research Institute) for sample preparation and analysis, Dr. Masashi Nagata, Dr. Yoshikane Yamauchi, Dr. Naoko Miyata, Dr. Hideaki Kojima, Dr. Yoshiki Kozu, Dr. Chihiro Yamatani, Dr. Kazuo Nakagawa, and Dr. Haruhiko Kondo (Division of Thoracic Surgery), and Dr. Haruyasu Murakami, Dr. Tateaki Naito, Dr. Hisao Imai, Dr. Hiroaki Akamatsu, Dr. Kazushige Wakuda, Dr. Takuya Oyakawa, Dr. Yasushi Hisamatsu, Dr. Ryo Ko, Dr. Shota Omori, Dr. Kazuhisa Nakashima, Dr. Takehito Shukuya, Dr. Yukiko Nakamura, Dr. Asuka Tsuya, Dr. Madoka Kimura, Dr. Takaaki Tokito, Dr. Hirofumi Eida, and Dr. Chikara Sakaguchi (Division of Thoracic Oncology, Shizuoka Cancer Center) for their contributions to this study.

\section{Funding}

This work was supported by JSPS KAKENHI Grant Numbers 24591186 (NY) and 24501363 (YK).

\section{Author details}

'Division of Thoracic Oncology, Shizuoka Cancer Center, 1007

Shimonagakubo, Nagaizumi-cho, Sunto-gun, Shizuoka 411-8777, Japan. ${ }^{2}$ Division of Drug Discovery and Development, Shizuoka Cancer Center Research Institute, Nagaizumi-cho, Sunto-gun, Japan. ${ }^{3}$ Division of Thoracic Surgery, Shizuoka Cancer Center, Nagaizumi-cho, Sunto-gun, Japan. ${ }^{4}$ Clinical Trial Coordination Office, Shizuoka Cancer Center, Nagaizumi-cho, Sunto-gun, Japan. ${ }^{5}$ Division of Diagnostic Radiology, Shizuoka Cancer Center,

Nagaizumi-cho, Sunto-gun, Japan. ${ }^{6}$ Division of Pathology, Shizuoka Cancer Center, Nagaizumi-cho, Sunto-gun, Japan. ${ }^{7}$ Third Department of Internal Medicine, Wakayama Medical University, Kimiidera, Wakayama, Japan.

Received: 26 February 2014 Accepted: 9 October 2014 Published: 28 October 2014

\section{References}

1. Scagliotti GV, Parikh P, von Pawel J, Biesma B, Vansteenkiste J, Manegold C, Serwatowski P, Gatzemeier U, Digumarti R, Zukin M, Lee JS, Mellemgaard A, Park K, Patil S, Rolski J, Goksel T, de Marinis F, Simms L, Sugarman KP, Gandara D: Phase III study comparing cisplatin plus gemcitabine with cisplatin plus pemetrexed in chemotherapy-naive patients with advancedstage non-small-cell lung cancer. J Clin Oncol 2008, 26(21):3543-3551.

2. Sandler A, Gray R, Perry MC, Brahmer J, Schiller JH, Dowlati A, Lilenbaum R, Johnson DH: Paclitaxel-carboplatin alone or with bevacizumab for non-small-cell lung cancer. N Engl J Med 2006, 355(24):2542-2550.

3. Mok TS, Wu YL, Thongprasert S, Yang CH, Chu DT, Saijo N, Sunpaweravong P, Han B, Margono B, Ichinose Y, Nishiwaki Y, Ohe Y, Yang JJ, Chewaskulyong B, Jiang H, Duffield EL, Watkins CL, Armour AA, Fukuoka M: Gefitinib or 
carboplatin-paclitaxel in pulmonary adenocarcinoma. N Eng/ J Med 2009, 361(10):947-957.

4. Maemondo M, Inoue A, Kobayashi K, Sugawara S, Oizumi S, Isobe H, Gemma A, Harada M, Yoshizawa H, Kinoshita I, Fujita Y, Okinaga S, Hirano S, Yoshimori K, Harada T, Ogura T, Ando M, Miyazawa H, Tanaka T, Saijo Y, Hagiwara K, Morita S, Nukiwa T: Gefitinib or chemotherapy for non-smallcell lung cancer with mutated EGFR. N Eng/ J Med 2010, 362(25):2380-2388.

5. Mitsudomi T, Morita S, Yatabe Y, Negoro S, Okamoto I, Tsurutani J, Seto T, Satouchi M, Tada H, Hirashima T, Asami K, Katakami N, Takada M, Yoshioka H, Shibata K, Kudoh S, Shimizu E, Saito S, Toyooka S, Nakagawa K, Fukuoka M: Gefitinib versus cisplatin plus docetaxel in patients with non-small-cell lung cancer harbouring mutations of the epidermal growth factor receptor (WJTOG3405): an open label, randomised phase 3 trial. Lancet Oncol 2010, 11(2):121-128.

6. Kwak EL, Bang YJ, Camidge DR, Shaw AT, Solomon B, Maki RG, Ou SH, Dezube BJ, Janne PA, Costa DB, Varella-Garcia M, Kim WH, Lynch TJ, Fidias P, Stubbs H, Engelman JA, Sequist LV, Tan W, Gandhi L, Mino-Kenudson M, Wei GC, Shreeve SM, Ratain MJ, Settleman J, Christensen JG, Haber DA, Wilner K, Salgia R, Shapiro Gl, Clark JW, et al.: Anaplastic lymphoma kinase inhibition in non-small-cell lung cancer. N Engl J Med 2010, 363(18):1693-1703.

7. Shaw AT, Kim DW, Nakagawa K, Seto T, Crino L, Ahn MJ, De Pas T, Besse B, Solomon BJ, Blackhall F, Wu YL, Thomas M, O'Byrne KJ, Moro-Sibilot D, Camidge DR, Mok T, Hirsh V, Riely GJ, lyer S, Tassell V, Polli A, Wilner KD, Janne PA: Crizotinib versus chemotherapy in advanced ALK-positive lung cancer. N Engl J Med 2013, 368(25):2385-2394.

8. Comprehensive genomic characterization of squamous cell lung cancers. Nature 2012, 489(7417):519-525.

9. Paik PK, Hasanovic A, Wang L, Rekhtman N, Ladanyi M, Kris MG: Multiplex testing for driver mutations in squamous cell carcinomas of the lung. ASCO Meeting Abstracts 2012, 30(15_suppl):7505.

10. Kim Y, Hammerman PS, Kim J, Yoon JA, Lee Y, Sun JM, Wilkerson MD, Pedamallu CS, Cibulskis K, Yoo YK, Lawrence MS, Stojanov P, Carter SL, McKenna A, Stewart C, Sivachenko AY, Oh IJ, Kim HK, Choi YS, Kim K, Shim YM, Kim KS, Song SY, Na KJ, Choi YL, Hayes DN, Cho S, Kim YC, Ahn JS, Ahn MJ, et al:: Integrative and comparative genomic analysis of lung squamous cell carcinomas in East asian patients. J Clin Oncol 2014, 32(2):121-128.

11. Dearden S, Stevens J, Wu YL, Blowers D: Mutation incidence and coincidence in non small-cell lung cancer: meta-analyses by ethnicity and histology (mutMap). Ann Oncol 2013, 24(9):2371-2376.

12. Pao W, Girard N: New driver mutations in non-small-cell lung cancer. Lancet Oncol 2011, 12(2):175-180.

13. Oxnard GR, Binder A, Janne PA: New targetable oncogenes in non-smallcell lung cancer. J Clin Oncol 2013, 31(8):1097-1104.

14. Gadgeel SM: New targets in non-small cell lung cancer. Curr Oncol Rep 2013, 15(4):411-423.

15. Su Z, Dias-Santagata D, Duke M, Hutchinson $K$, Lin $Y L$, Borger DR, Chung $C H$, Massion PP, Vnencak-Jones $\mathrm{CL}$, lafrate AJ, Pao W: A platform for rapid detection of multiple oncogenic mutations with relevance to targeted therapy in non-small-cell lung cancer. J Mol Diagn 2011, 13(1):74-84.

16. Serizawa M, Koh Y, Kenmotsu H, Isaka M, Murakami H, Akamatsu H, Mori K, Abe M, Hayashi I, Taira T, Maniwa T, Takahashi T, Endo M, Nakajima T, Ohde $\mathrm{Y}$, Yamamoto $\mathrm{N}$ : Assessment of mutational profile of Japanese lung adenocarcinoma patients by multitarget assays: a prospective single-institute study. Cancer 2014, 120(10):1471-1481.

17. Ross JS, Cronin M: Whole cancer genome sequencing by next-generation methods. Am J Clin Pathol 2011, 136(4):527-539.

18. Khuder SA: Effect of cigarette smoking on major histological types of lung cancer: a meta-analysis. Lung Cancer 2001, 31(2-3):139-148.

19. Moses W, Weng J, Khanafshar E, Duh QY, Clark OH, Kebebew E: Multiple genetic alterations in papillary thyroid cancer are associated with younger age at presentation. J Surg Res 2010, 160(2):179-183.

20. Onozato W, Yamashita K, Kuba T, Katoh H, Nakamura T, Sato T, Ihara A, Okayasu I, Watanabe M: Genetic alterations of K-ras may reflect prognosis in stage III colon cancer patients below 60 years of age. J Surg Oncol 2011, 103(1):25-33

21. Ueno T, Toyooka S, Suda K, Soh J, Yatabe Y, Miyoshi S, Matsuo K, Mitsudomi T: Impact of age on epidermal growth factor receptor mutation in lung cancer. Lung Cancer 2012, 78(3):207-211.
22. Liu D, Hou P, Liu Z, Wu G, Xing M: Genetic alterations in the phosphoinositide 3-kinase/Akt signaling pathway confer sensitivity of thyroid cancer cells to therapeutic targeting of Akt and mammalian target of rapamycin. Cancer Res 2009, 69(18):7311-7319.

23. Yamamoto H, Shigematsu H, Nomura M, Lockwood WW, Sato M, Okumura N Soh J, Suzuki M, Wistuba II, Fong KM, Lee H, Toyooka S, Date H, Lam WL, Minna JD, Gazdar AF: PIK3CA mutations and copy number gains in human lung cancers. Cancer Res 2008, 68(17):6913-6921.

24. Kawano O, Sasaki H, Endo K, Suzuki E, Haneda H, Yukiue H, Kobayashi Y, Yano M, Fujii Y: PIK3CA mutation status in Japanese lung cancer patients. Lung Cancer 2006, 54(2):209-215.

25. Koh Y, Kenmotsu H, Serizawa M, Isaka M, Mori K, Imai H, Akamatsu H, Ono A, Naito T, Taira T, Murakami H, Takahashi T, Endo M, Nakajima T, Ohde Y, Yamamoto N: Identification of actionable mutations in surgically resected tumor specimens from Japanese patients with non-small cell lung cancer by ultra-deep targeted sequencing. ASCO Meeting Abstracts 2013, 31(15_suppl):7572.

26. Brooks AN, Kilgour E, Smith PD: Molecular pathways: fibroblast growth factor signaling: a new therapeutic opportunity in cancer. Clin Cancer Res 2012, 18(7):1855-1862.

27. Drilon A, Rekhtman N, Ladanyi M, Paik P: Squamous-cell carcinomas of the lung: emerging biology, controversies, and the promise of targeted therapy. Lancet Oncol 2012, 13(10):e418-e426.

28. Heist RS, Mino-Kenudson M, Sequist LV, Tammireddy S, Morrissey L, Christiani DC, Engelman JA, lafrate AJ: FGFR1 amplification in squamous cell carcinoma of the lung. J Thorac Oncol 2012, 7(12):1775-1780.

29. Sasaki H, Shitara M, Yokota K, Hikosaka Y, Moriyama S, Yano M, Fujii Y: Increased FGFR1 copy number in lung squamous cell carcinomas. Mol Med Rep 2012, 5(3):725-728.

30. Kim HR, Kim DJ, Kang DR, Lee JG, Lim SM, Lee CY, Rha SY, Bae MK, Lee YJ, Kim SH, Ha SJ, Soo RA, Chung KY, Kim JH, Lee JH, Shim HS, Cho BC: Fibroblast growth factor receptor 1 gene amplification is associated with poor survival and cigarette smoking dosage in patients with resected squamous cell lung cancer. J Clin Oncol 2013, 31(6):731-737.

31. Gerlinger M, Rowan AJ, Horswell S, Larkin J, Endesfelder D, Gronroos E, Martinez P, Matthews N, Stewart A, Tarpey P, Varela I, Phillimore B, Begum S, McDonald NQ Butler A, Jones D, Raine K, Latimer C, Santos CR, Nohadani M, Eklund AC, Spencer-Dene B, Clark G, Pickering L, Stamp G, Gore M, Szallasi Z, Downward J, Futreal PA, Swanton C: Intratumor heterogeneity and branched evolution revealed by multiregion sequencing. N Engl I Med 2012, 366(10):883-892.

doi:10.1186/1471-2407-14-786

Cite this article as: Kenmotsu et al:: Prospective genetic profiling of squamous cell lung cancer and adenosquamous carcinoma in Japanese patients by multitarget assays. BMC Cancer 2014 14:786.

\section{Submit your next manuscript to BioMed Central and take full advantage of:}

- Convenient online submission

- Thorough peer review

- No space constraints or color figure charges

- Immediate publication on acceptance

- Inclusion in PubMed, CAS, Scopus and Google Scholar

- Research which is freely available for redistribution 